\title{
JURNAL
}

\section{Perancangan dan analisis sistem keamanan jaringan komputer menggunakan SNORT}

\author{
Winrou Wesley Purba ${ }^{1}$, Rissal Efendi ${ }^{2}$ \\ ${ }^{1,2}$ Fakultas Teknologi Informasi Universitas Kristen Satya Wacana \\ J1. Dr. O. Notohamidjojo 1-10, Salatiga 50711, Indonesia \\ Email :1672016259@student.uksw.edu, ${ }^{2}$ rissal.efendi@uksw.edu
}

\section{Abstract}

PT. Promanufacture Indonesia is a company that needs the Internet network to be able to process the data of members, goods, CCTV and others. All files and data of members, goods, CCTV and others will be stored in a server. The Server at PT. Promanufacture Indonesia relies only on firewall systems. By using the firewall alone network security system will not be guaranteed, but with SNORT, the computer safety system will be more maintained by the warnings that will be given by the SNORT. SNORT is a piece of software that will give you a warning when intrusion occurs into your computer system. The purpose of this research is to design and analyze computer security system in PT. Promanufacture Indonesia by using SNORT software. The results of this research can be used by the network manager of PT. Promanufacture Indonesia to maintain the security system of computer networks in the company.

Keywords: SNORT, Network Security, System Firewall

\begin{abstract}
Abstrak
PT. Promanufacture Indonesia merupakan sebuah perusahaan yang memerlukan adanya jaringan internet agar dapat mengolah data anggota, barang, CCTV dan lain-lain. Semua file dan data anggota, barang, CCTV dan lain-lain akan disimpan di dalam sebuah server. Server di PT. Promanufacture Indonesia hanya mengandalkan sistem firewall saja. Dengan menggunakan firewall saja sistem keamanan jaringan tidak akan terjamin keamanannya. Maka diperlukan sebuah sistem untuk menjaga keamanan jaringan tersebut, yaitu SNORT. SNORT merupakan perangkat lunak yang akan memberikan peringatan ketika terjadi penyusupan kedalam sistem komputer. Tujuan dari penelitian ini adalah merancang dan menganalisa sistem keamanan komputer di PT. Promanufacture Indonesia dengan menggunakan perangkat lunak SNORT. Hasil dari penelitian ini dapat digunakan oleh pengelola jaringan PT. Promanufacture Indonesia untuk menjaga sistem keamanan jaringan komputer pada perusahaan tersebut.
\end{abstract}

Kata kunci: SNORT, Keamanan Jaringan, Sistem Firewall 


\section{Pendahuluan}

Pada saat ini perkembangan teknologi sangatlah pesat apalagi dengan didukungnya fasilitas internet yang sangat mumpuni. Namun disamping itu semua pasti selalu ada kerugian yang didapat oleh pengguna internet tersebut. Seperti serangan dari pihak-pihak yang tidak bertanggung jawab atau sering disebut dengan hacker. Oleh karena itu seorang administrator jaringan harus memastikan bahwa sistem jaringan komputer sebuah perusahaan harus aman dari serangan hacker. Ada banyak jenis serangan yang mampu dilakukan oleh hacker agar mampu masuk ke sistem komputer yang dituju, tapi jenis serangan Port Scanning dan DOS (Denial of Service) merupakan jenis serangan yang sering digunakan oleh hacker. Port Scanning merupakan sebuah serangan yang dilakukan untuk mendeteksi port yang terbuka pada sistem jaringan komputer, dari hasil port scanning akan didapat portport yang terbuka, Port tersebut yang akan menjadi celah untuk melakukan penyerangan lebih lanjut. Sedangkan DOS (Denial of Service) adalah sebuah serangan pada jaringan komputer yang beroperasi dengan cara mengirimkan request ke server secara terus-menerus agar membuat server tersebut menjadi sibuk dan server tidak bisa mengatasi request yang telah diterima dan membuat server tersebut menjadi rusak.

Penelitian ini dilakukan di perusahaan PT. Promanufacture Indonesia untuk membantu kinerja perusahaan tersebut. PT. Promanufacture Indonesia merupakan sebuah perusahaan yang aktivitasnya didukung oleh jaringan internet, mulai dari mengolah data yang ada seperti data anggota, barang, CCTV dan lain-lain. Pengelola jaringan PT. Promanufacture Indonesia selama ini membangun sistem keamanan jaringan dengan menerapkan sistem firewall pada tiap unit server di jaringannya.

Pada jaringan lokal PT. Promanufacture Indonesia menggunakan kelas subnet /16, dengan jumlah maksimal 16.777.214 host, namun saat ini baru digunakan 857 host, baik untuk komputer maupun perangkat aktif lainnya. Sistem Operasi yang digunakan pada PT. Promanufacture Indonesia adalah Microsoft Windows XP, Microsoft Windows 7, Windows 10, Linux Ubuntu, Linux Xubuntu.

Dengan adanya sistem keamanan firewall, sistem jaringan komputer telah banyak membantu administrator untuk mengamankan data perusahaan, tapi dengan seiring berjalannya waktu, semakin lama perkembangan teknologi semakin meningkat, sistem keamanan firewall belum mampu menjamin keamanan sistem komputer sepenuhnya. Sehingga perusahaan PT. Promanufacture Indonesia memiliki masalah pada sistem jaringan komputer karena hanya mengandalkan sistem firewall saja.

Sistem keamanan firewall dirancang untuk mengawasi paket yang keluar dan masuk dari jaringan, sehingga paket yang mencurigakan akan langsung dihentikan tanpa memisahkan apakah paket tersebut aman atau tidak, akibatnya 
administrator sering sekali tertipu oleh serangan yang tidak dapat diklasifikasikan. Beberapa kasus yang terjadi pada perusahaan PT. Promanufacture Indonesia diantaranya pada bulan September 2019 sebuah PC dengan sistem operasi Windows XP terkena virus ransomware yang mengunci data penting yang ada di PC tersebut. Adanya virus ransomware diketahui melalui anti virus Avast. Kasus lain terjadi pada bulan Januari 2019 yaitu adanya sebuah email yang masuk ke perusahaan yang berisi virus Worm yang ingin mencuri data perusahaan.

Oleh karena itu, keamanan jaringan firewall saja tidak cukup untuk melindungi sistem jaringan komputer. Dibutuhkan keamanan yang dapat menjamin agar dapat meminimalisir ataupun bahkan menghilangkan kerugian yang disebabkan oleh serangan keamanan jaringan tersebut yaitu menggunakan SNORT. SNORT dapat meminimalisir serangan-serangan yang terjadi di dalam sistem jaringan komputer dengan cara memberikan allert atau peringatan kepada administrator jika ada kegiatan yang mencurigakan.

\section{Kajian Pustaka}

Banyak penelitian tentang keamanan jaringan yang telah dilakukan. Wijanarko[1] menggunakan SNORT untuk deteksi intrusi dari external network. Dalam rancangannya, Wijanarko menggunakan SMS gateway yang digunakan untuk mengirimkan notifikasi kepada administrator jika terjadi serangan. Sudradjat[2] menggabungkan Firewall dan SNORT untuk mendeteksi dan mencegah penyusup pada jaringan komputer.

Jaringan komputer merupakan kumpulan dari beberapa komputer yang berjumlah banyak yang terpisah-pisah namun dapat saling terkoneksi atau saling terhubung dalam melaksanakan tugasnya. Contohnya, seperti dua buah komputer dapat dikatakan saling terhubung apabila keduanya dapat saling berbagi data, bertukar informasi, program-program, dan sebagainya. Contoh lain dari jaringan komputer adalah LAN (Local Area Network), MAN (Metropolitan Area Network), WAN (Wide Area Network). Jaringan komputer dapat dihubungkan melalui berbagai kabel, seperti kabel tembaga, kabel coaxial, kabel twisted pair, kabel serat optik dan berbagai teknologi wireless[3].

IDS (Intrution Detection System) merupakansebuah perangkat yang dapat melakukan pengawasan secara otomatis terhadap lalu lintas jaringan yang mencurigakan[7]. Jika terjadi hal yang tidak lazim atau hal yang mencurigakan, maka IDS akan memberikan informasi kepada sistem dan administrator jaringan. Ada dua bentuk dasar IDS yang sering digunakan yaitu: NIDS dan HIDS.

NIDS (Network - based Intrusion Detection System) merupakan sebuah perangkat lunak yang bekerja secara otomatis untuk memantau suatu paket data yang masuk ke dalam sistem jaringan. Semua paket data yang berjalan pada sistem jaringan, akan dianalisis untuk melihat apakah ada percobaan serangan atau penyusupan ke dalam sistem jaringan. Jika ada kecocokan dengan rules yang telah dibuat, maka 
hasilnya akan dicatat dalam sebuah file[4]. HIDS (Host Intrusion Detection System) merupakan jenis IDS yang bekerja pada host yang individual atau perangkat tertentu pada sistem jaringan komputer secara real-time. HIDS akan memantau paket-paket data ketika sedang terjadi penyusupan saja.[2]

SNORT merupakan sebuah aplikasi keamanan jaringan yang berfungsi dalam mendeteksi adanya ancaman dalam jaringan komputer, seperti penyusup, pemindaian, maupun penyerangan. SNORT merupakan gabungan dari protokol analisis dan pendeteksi penyusupan yang berguna untuk merespon kejadiankejadian yang sedang terjadi pada jaringan komputer secara real-time. SNORT akan merespon kejadian yang terjadi dalam penyerangan host-host jaringan [3].

SNORT memiliki fitur-fitur yang dapat menjaga kemanan sistem jaringan dengan cara memberikan peringatan atau allert dan juga meng-capture setiap sesi yang sedang berjalan. Dengan adanya fitur ini menjadikan SNORT merupakan sistem yang mampu mendeteksi adanya ancaman pada sistem jaringan yang sangat berguna pada user[3]. SNORT dapat dioperasikan dengan 3 mode, yaitu:

1. Sniffer mode, pada mode operasi ini SNORT dapat menangkap atau melihat semua paket yang sedang berjalan dalam jaringan dimana SNORT diletakkan. SNORT juga memiliki kemampuan menampilkan hasil sniffing secara real time.

2. Packet logger mode, pada mode ini SNORT mencatat setiap paket yang berjalan dan mengubahnya ke dalam bentuk file.

3. Network intrusion detection mode, pada mode ini SNORT berjalan dengan melakukan konfigurasi yang kompleks terlebih dahulu, yaitu menjalankan SNORT beserta file konfigurasi yang sudah ditentukan (secara default file snort.conf).

Keamanan jaringan adalah konsep untuk mencegah pengguna yang tidak sah masuk kedalam sistem jaringan komputer[5]. Sistem harus tetap dilindungi dari segala macam serangan dan usaha penyusupan atau pemindaian oleh pihak yang tidak memiliki hak. Langkah-langkah pencegahan dapat membantu administrator untuk menghentikan pengguna yang tidak sah untuk mengakses sistem jaringan komputer.

Keamanan jaringan komputer berfungsi untuk mengantisipasi resiko-resiko yang akan terjadi pada jaringan komputer yang dapat menggangu aktivitas yang sedang terjadi pada sistem jaringan komputer [3]. Ada tiga hal dalam konsep keamanan jaringan, yaitu ingkat bahaya, ancaman dan kerapuhan sIstem.

John D. Howard berpendapat dalam bukunya yang berjudul "An Analysis of security incidents on the internet" bahwa: "Keamanan komputer adalah tindakan pencegahan dari serangan pengguna komputer atau pengakses jaringan yang tidak bertanggung jawab". 
Penerapan sistem keamanan jaringan dengan menggunakan aplikasi SNORT ini merupakan salah satu solusi yang dapat membantu sistem keamanan jaringan agar tetap terjaga dari penyusup yang mencoba masuk ke dalam sistem jaringan komputer. SNORT bekerja dengan cara memantau kondisi jaringan dan menganalisa paket-paket berbahaya yang terdapat dalam jaringan tersebut.

\section{Metode Penelitian}

PPDIOO adalah sebuah metode perancangan jaringan yang dirancang untuk mendukung berkembangnya jaringan. PPDIOO terdiri dari beberapa tahapan, yaitu Prepare, Plan, Design, Implement, Operate, dan Optimize. Dengan kebutuhan layanan jaringan yang semakin kompleks, maka diperlukan suatu metodologi yang mendukung perancangan arsitektur dan disain jaringan[9].

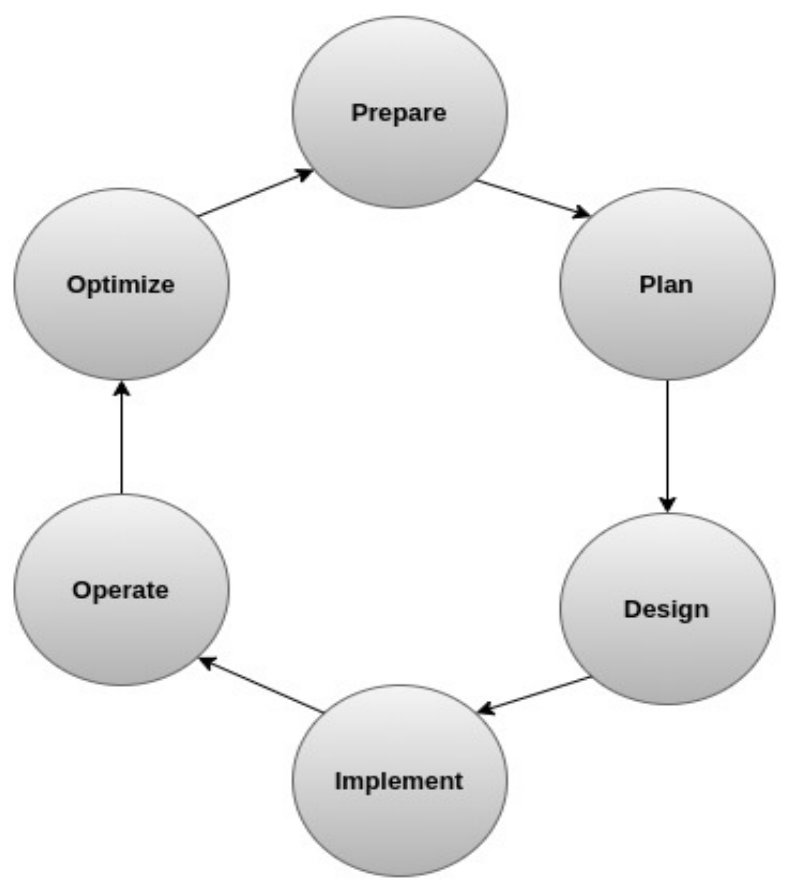

Gambar 1 Tahapan penelitian

1) Prepare Phase

Pada tahap ini, melakukan persiapan membangun sistem keamanan jaringan menggunakan SNORT, yaitu mulai mempersiapkan kebutuhan, konsep, dan strategi financial. Ada beberapa langkah yang akan dilakukan dalam tahap Prepare Phase, yaitu mempersiapkan:

1. Sebuah komputer atau laptop yang digunakan sebagai intruder (penyerang) dengan spesifikasi: Sistem Operasi Linux (Distro Linux Mint) dan RAM 2 Gigabyte. 
2. Sebuah komputer atau laptop yang digunakan sebagai server SNORT dengan spesifikasi: Sistem Operasi Windows 10 dan RAM 8 Gigabyte.

3. Sebuah PC yang diserang oleh intruder (penyerang) dengan spesifikasi: Sistem Operasi Windows 10. Dan RAM 8 Gigabyte.

4. Switch

5. Kabel UTP untuk menghubungkan PC client dan server SNORT.

6. Jaringan Internet.

7. Access Point.

8. Sebuah software SNORT.

2) Plan Phase

Pada tahap ini dilakukan identifikasi hal-hal yang harus dipenuhi berdasarkan tujuan, fasilitas dan kebutuhan pengguna. Perencanaan yang dilakukan adalah :

1. Mengunduh software SNORT pada PC server

2. Mengunduh tool untuk menyerang PC server pada PC attacker

3. Memilih jenis serangan

4. Memilih skema jaringan

3) DesignPhase

Dalam tahap ini, dilakukan desain jaringan yang terperinci yang akan memenuhi persyaratan teknis. Topologi yang digunakan pada tahap ini ditunjukkan pada Gambar 2.

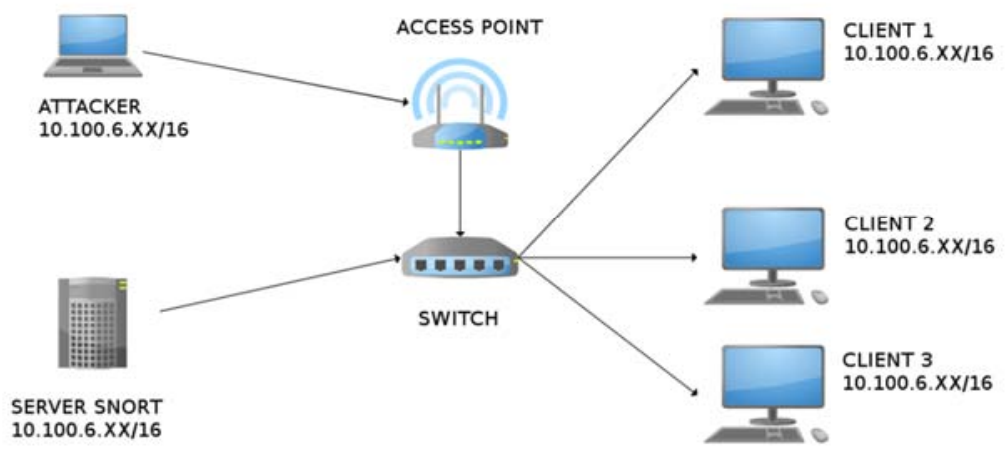

\section{4) Implement Phase}

Gambar 2 Topologi jaringan

Pada fase ini, dilakukan instalasi dan konfigurasi yang sesuai dengan spesifikasi desain. Dengan menginstal software dan konfigurasi dan pemilihan serangan yang diujicoba pada sistem jaringan komputer. Tahap-tahap yang dilakukan pada fase ini adalah sebagai berikut :

1. Menginstal softwareSNORT pada PC server. 
2. Melakukan konfigurasi SNORT pada PC server.

3. Menginstal tools penyerangan pada $\mathrm{PC}$ attacker.

4. Melakukan konfigurasi tool penyerangan pada PC attacker.

5. Menghubungkan kabel LAN dari switch ke access point.

6. Menghubungkan kabel LAN dari PC client ke switch.

7. Menghubungkan PC attacker ke jaringan internet.

8. Melakukan penyerangan terhadap PC client dengan metode penyerangan Ping Flood.

9. SNORT membaca jika terjadi penyerangan terhadap PC client.

\section{5) Operational Phase}

Fase operasional adalah mempertahankan ketahanan kegiatan jaringan, dimana pada fase ini meliputi pengolahan komponen jaringan, melakukan pemeliharaan sistem jaringan, mengelola kinerja jaringan, dan mengoreksi jika ada kesalahan pada jaringan. Pada fase ini, aplikasi SNORT dijalankan sesuai dengan rencana yang telah ditentukan.

6) Optimaze Phase

Fase Optimalisasi, administrator jaringan mengidentifikasi dan menyelesaikan masalah yang sedang terjadi. Kemungkinan di fase optimalisasi akan dilakukan modifikasi desain jaringan, jika terlalu banyak masalah yang timbul. Pada fase ini Administrator akan menilai apakah SNORT mampu bekerja secara maksimal atau tidak. Jika bekerja secara maksimal, maka SNORT sangat berfungsi untuk meminimalisi penyerangan yang terjadi pada sistem jaringan komputer, namun jika tidak, aplikasi SNORT masih kurang aman untuk meminimalisir penyerangan yang terjadi pada sistem jaringan komputer.

\section{Hasil dan Pembahasan}

Penelitian ini dilakukan dengan menghubungkan beberapa komputer yaitu terdiri dari komputer server,client, dan attacker. Komputer server telah diinstal softwareSNORT yang berfungsi untuk menangkap paket yang menuju ke komputer server tersebut, Sedangkan komputer attacker telah diinstal software hping3 yang berfungsi untuk melakukan serangan DDOS Attack ke server. Pada jaringan kali ini

disambungkan menggunakan switch. Berikut langkah-langkah yang dilakukan pada penelitian ini.

1. Instalasi Jaringan 
Pada penelitian ini jaringan yang digunakan adalah jaringan lokal yang terdiri dari 1 komputer server, 1 komputer attacker, dan 1 komputer client. Komputer-komputer tersebut memiliki IP address sebagai berikut :

$$
\begin{array}{ll}
\text { - Server } & : 10.100 .3 .147 \\
\text { - client } & : 10.100 .4 .88 \\
\text { - attacker } & : 10.100 .6 .77
\end{array}
$$

\section{Instalasi SNORT}

SoftwareSNORT diinstal pada komputer server yang akan digunakan untuk membaca paket-paket yang menuju ke server tersebut. Aplikasi SNORT dapat didownload pada website https://www.snort.org/downloads. Pada website tersebut user harus men-downloadsoftware SNORT dan rules.

Setelah selesai menginstal SNORT, user terlebih dahulu harus mengkonfigurasi SNORT tersebut agar dapat menangkap paket-paket yang menuju ke komputer server. User harus menambahkan direktori pada rules SNORT agar SNORT dapat membedakan paket-paket yang menuju komputer server, apakah itu merupakan paket yang berbahaya atau bukan. Ada beberapa hal yang perlu dikonfigurasi, yaitu:

1) Konfigurasi $I P$ address agar dapat membaca lalu lintas jaringan dan konfigurasi lokasi rules agar dapat membaca aturan yang ada pada SNORT.

Kode Program 1 konfigurasi IP address pada SNORT

1. var HOME_NET 10.100.0.254/16

2. var EXTERNAL_NET ! \$HOME_NET

3. var RULE_PATH C: \Snort $\backslash$ rules

4. var PREPROC RULE_PATH c: \Snort \preproc_rules

5. var WHITE_LIST_PATH $c: \backslash S n o r t \backslash r u l e s$

6. var BLACK_LIST_PATH c: \Snort \rules

2) Agar server dapat membaca intrusi, maka perlu menambahkan rules pada file local.rules yang terletak pada direktori C:/snort/rules/

Kode Program 2 membuat rules yang akan dibaca oleh SNORT

1. alert icmp any any -> \$HOME_NET any (msg:"PING to Server!!!!!"; sid:1000001;)

2. alert tcp any any $\rightarrow$ \$HOME_NET any (msg:"Possible DoS Attack";flags:S; flow:stateless; detection_filter:track by_dst, count 100, seconds 10; sid: 1000002 ; )

pada tahap ini user dapat menyimpan intrusi yang telah dibuat dengan menyimpan file yang telah ditambahkan

3. Mengaktifkan server SNORT

Setelah selesai mengkonfigurasi SNORT, maka SNORT perlu diaktifkan agar dapat agar dapat membaca paket-paket yang sedang menuju komputer 
server. Untuk mengaktifkan SNORT, perlu memasukkan perintah pada Windows dengan menggunakan $C M D$, yaitu:

Kode Program 3 Cara mengaktifkan SNORT

1. snort -i2 -c $c: \backslash s n o r t \backslash e t c \backslash s n o r t . c o n f$

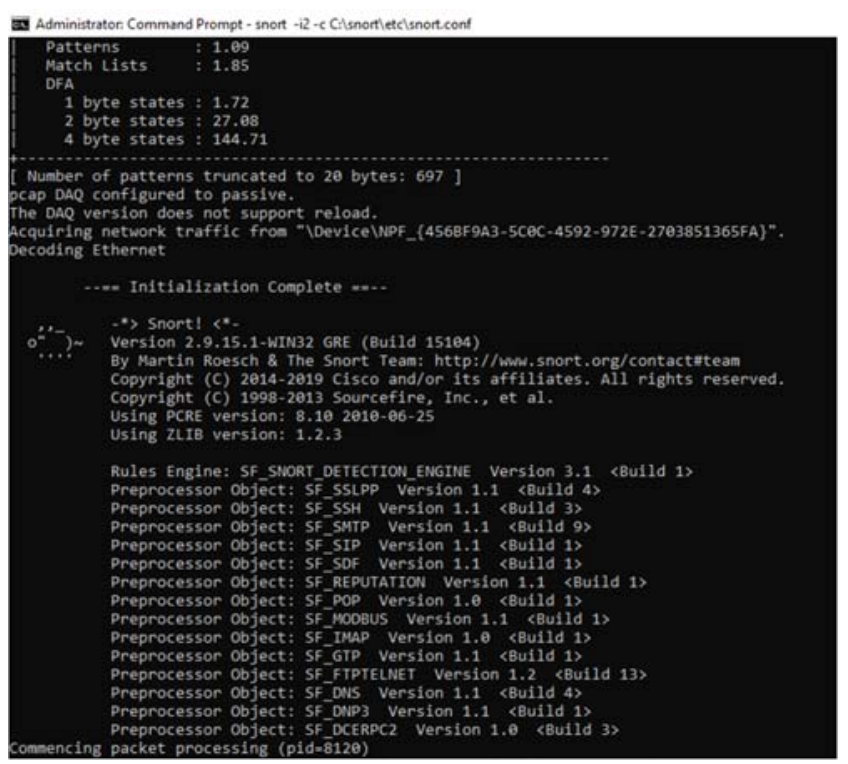

Gambar 3 Hasil konfigurasi SNORT

Pada Gambar 3 dapat dilihat bahwa SNORT telah aktif dan sudah siap digunakan untuk melakukan pendeteksian pada PC server.

\section{Melakukan Ping}

Untuk melakukan ping dari PC Client ke PC server dapat kita lakukan perintah sebagai berikut :

Kode Program 4 melakukan ping ke PC Server

1. Ping $10.100 .3 .147-\mathrm{t}$

Ping 10.100.3.147 -t berfungsi agar PC Client dapat melakukan cek koneksi ke PC server secara terus menerus tanpa berhenti. 


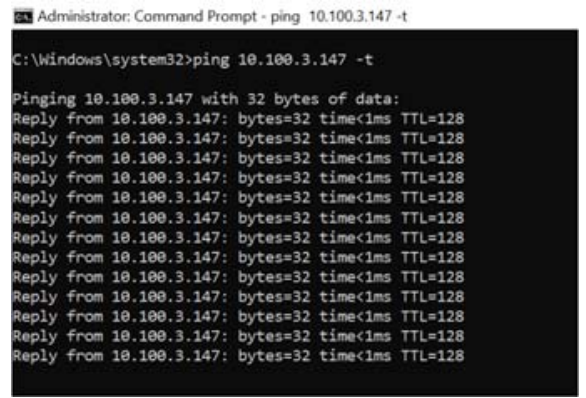

Gambar 4 Melakukan Ping

Pada Gambar 4 dapat dilihat bahwa IP address 10.100.4.88 akan melakukan ping ke server SNORT yang memiliki IP address 10.100.3.147. Pada baris "Pinging 10.100.3.147 with 32 bytes of data:" berisi bahwa host yang dituju oleh PC client adalah PC server yang memiliki IP address 10.100.3.147 dan besaran paket yang dikirim secara default, maka besaran paket yang dikirim adalah 32 bytes.

Pada baris "Reply from 10.100.3.147: bytes:32 time $<1 m s \quad T T L=128$ " merupakan pesan balasan yang diterima oleh PC client yang dimana "time $<1 \mathrm{~ms}$ " merupakan total waktu yang dibutuhkan agar sebuah paket dapat terkirim ke PC server, yaitu sekitar 1 millisecond(ms) dan juga TTL(time to live) yang merupakan waktu maksimum PC server saat membalas paket yang dikirm olehPC client, yaitu dengan jumlah 128.

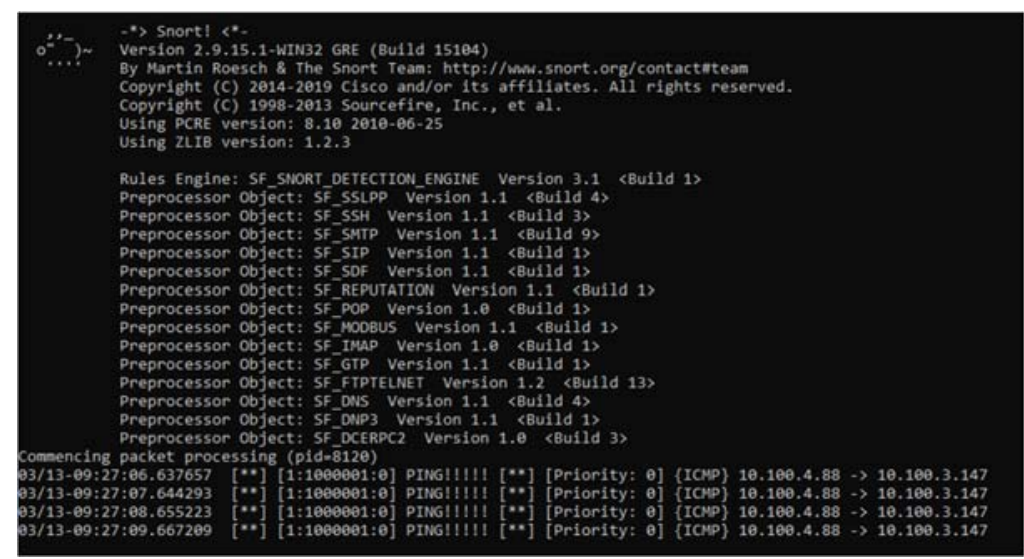

Gambar 5 Hasil Ping dideteksi oleh SNORT

Pada Gambar 5 dapat dilihat bahwa server SNORT sedang mendeteksi adanya ping menuju server komputer dan menunjukkan waktu dan tanggal serta $I P$ address yang mencoba ping ke server SNORT

\section{DDOSAttack}


Komputer attacker akan mencoba melakukan DDOS Attack ke server SNORT dengan metode Pingfloodattack. Pingflood merupakan sebuah metode penyerangan dengan cara membanjiri paket data dalam waktu singkat sehingga dapat membuat komputer target menjadi error bahkan sampai rusak. Metode ini juga dapat membuat komputer itu tidak dapat berbagi file atau data ke komputer lain. Pada percobaan ini attacker yang memiliki IP address 10.100.6.77 mencoba melakukan Pingflood ke server komputer yang memiliki IP address 10.100.3.147.

Pada penelitian ini digunakan sistem operasi Linux untuk melakukan serangan DDOS Attack dengan menggunakan aplikasi "hping3". Sebelum melakukan DDOS Attack, terlebih dahulu user melakukan port scanning dari komputer attacker dengan menggunakan aplikasi "nmap". Untuk melakukan port scanning dapat dilakukan dengan perintah sebagai berikut :

Kode Program 5 Cara melakukan port scanning

1. Nmap 10.100 .3 .147

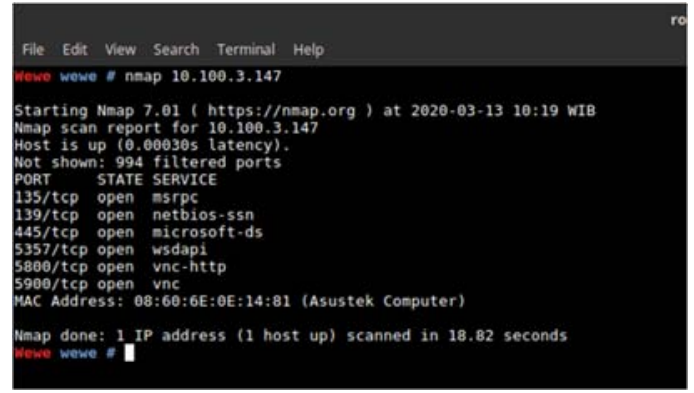

Gambar 6 Melakukan port scanning menggunakan nmap

Setelah selesai melakukan port scanning dapat pada Gambar 6 terdapat beberapa port yang terbuka pada PC server seperti port 135/tcp, 139/tcp, 445/tcp dan sebagainya. Port tersebut dapat dimanfaatkan sebagai celah untuk melakukan penyerangan.

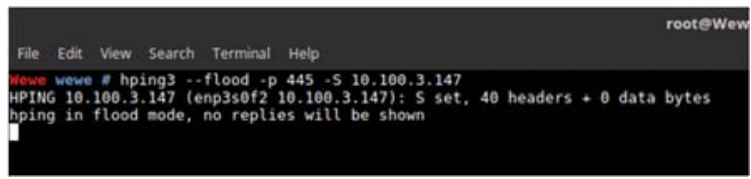

Gambar 7 Melakukan PingFlood

Pada Gambar 7 Attacker melakukan Pingflood dengan memanfaatkan port yang terbuka yaitu port 445. Untuk melakukan Pingflood perlu memasukkan perintah di dalam terminal sebagai berikut :

Kode Program 6 Cara melakukan Pingflood

1. Hping3 --flood -p 445 -S 10.100.3.147 
Pada baris perintah Kode Program 6 terdapat beberapa hal yang perlu dipahami, yaitu :

- Hping3 merupakan pemanggilan aplikasi Pingflood

- -flood merupakan perintah untuk membanjiri lalu lintas data

- -p 445 adalah port yang dituju, yaitu port 445

- -S 10.100.3.147 adalah IP address yang akan diserang, yaitu 10.100.3.147

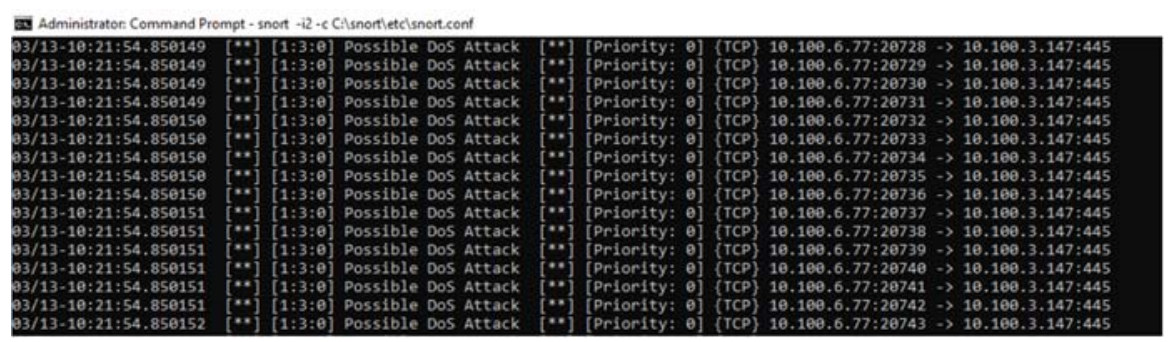

Gambar 8 Server SNORT mendeteksi adanya serangan

Dari Gambar 8 dapat dilihat bahwa adanya serangan DDOS Attack. SNORT juga dapat membaca waktu penyerangan, port yang diserang dan IP address mana yang menyerang komputer server.

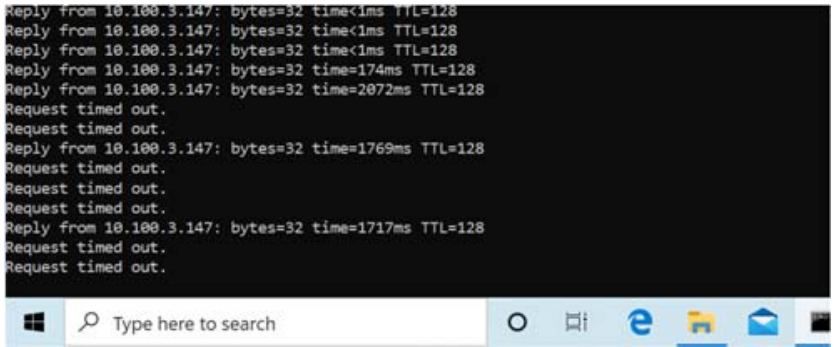

Gambar 9Ping ke server

Pada Gambar 9 terlihat proses ping dari komputer client ke komputer server. Ketika server SNORT sedang diserang oleh IP address 10.100.6.77 maka, ketika IP addressclient me-request ke server akan terjadi request timed out atau pun membutuhkan waktu yang sangat tinggi.

B) Hasil Analisa

1. Penambahan Rules

Pada penelitian ini dibuat beberapa rules, yaitu:

1. alert icmp any any -> \$HOME_NET any (msg: "PING to Server!!!!! "; sid:1000001;)

2. alert tcp any any $\rightarrow$ \$HOME_NET any (msg:"Possible DoS Attack";flags:S;

flow:stateless; detection_filter:track by_dst, count 100, seconds 10; sid:1000002; ) 
Dari aturan rules diatas dibuat untuk mendeteksi jika :

1) adanya ping ke komputer server.

2) jika ada yang melakukan percobaan serangan ke komputer server.

Dengan Keterangan sebagai berikut:

Rule Header :

- Alert adalah tanda peringatan.

- icmp dan tcp adalah jenis protokol transport.

- any adalah untuk melihat IP address. SNORT akan membaca semua sumber IP address yang mencoba masuk atau pun me-request sesuatu ke IP address komputer server.

- any adalah untuk membaca sumber port. SNORT akan membaca semua sumber port yang mencoba menyerang server komputer.

- $\rightarrow$ adalah aliran host asal ke host tujuan.

- \$HOME_NET adalah host awal yang melewati port manapun.

- any adalah untuk membaca tujuan port. SNORT akan membaca seluruh port yang akan dilindungi.

\section{Rule Option :}

- msg:"PING to Server!!!!!" dan msg:"Possible DoS Attack" merupakan pesan yang akan diberikan kepada administrator jika ada sesuatu hal yanng terjadi pada jaringan komputer.

- sid: 1000002 dan sid:1000001 adalah id.

- flag: S adalah kontrol bit yang berupa informasi bagaimana sebuah paket harus ditangani.

- flow:stateless adalah perintah untuk menentukan kemana paket data dikirim.

- detection_filter:track by_dst adalah SNORT akan melacak alamat IP address tujuan untuk dideteksi.

- count 100 adalah SNORT akan mencatat minimal 100 peristiwa berdasarkan IP address yang sama.

- second 10 adalah waktu yang diperlukan oleh IP address untuk melakukan pencatatan pada SNORT.

\section{2. $\operatorname{LogSNORT}$}

SNORT juga mampu mencatat setiap paket yang telah dideteksi oleh SNORT dalam bentuk file dan paket itu akan disimpan ke dalam disk komputer. Secara otomatis file tersebut akan tersimpan di directory C: $\mid$ snort $\log$. File $\log$ tersebut dapat dibuka menggunakan CMD dengan melakukan perintah C: $\mid$ snort $\mid \log \backslash$ snort.log. $\{$ angka acak\}. 
Kode Program 7 perintah untuk membuka log pada CMD

1. C: \snort $\backslash \log \backslash$ snort. $\log .1584069679$

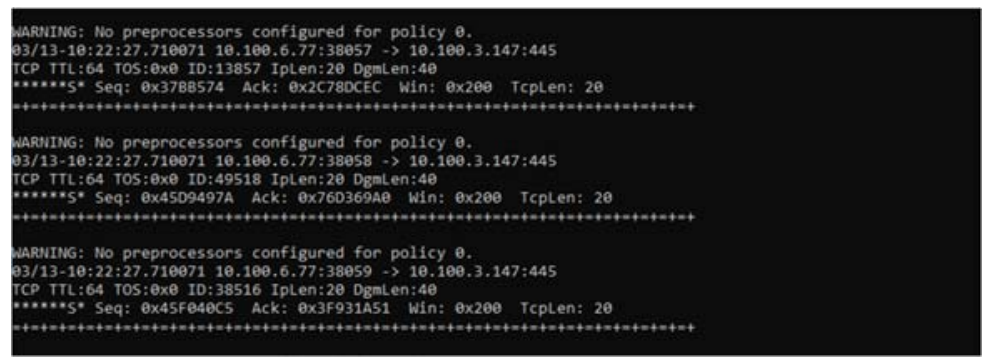

Gambar 10 Hasil Logger

Pada Gambar 10 terdapat beberapa hal yang perlu dipahami, yaitu: ,Pencatatan waktu yaitu 03/13-10.22.27, yang berarti SNORT mendeteksi penyerangan pada tanggal 13 maret tepat pada jam 10 lewat 22 menit 27 detik, IP addressattacker adalah 10.100.6.77, port yang digunakan oleh attacker untuk menyerang komputer server adalah port 445.

3. Pengaruh Pingflood

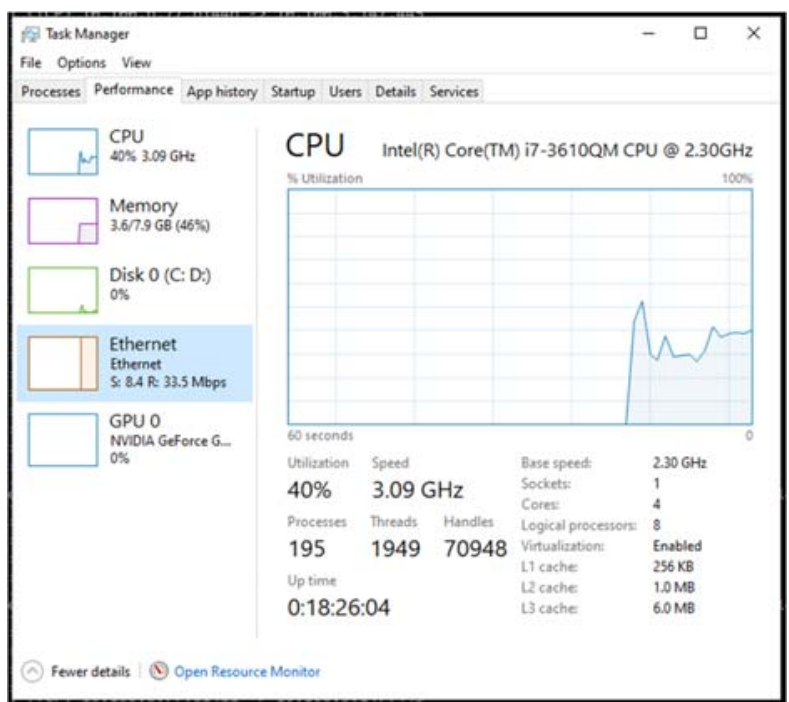

Gambar 11 Grafik Perfomance CPU

Dari Gambar 11 dapat dilihat bahwa grafik pada CPU sangat tinggi, ketika attacker melakukan penyerangan DDOS Attack, maka komputer akan bekerja secara lebih maksimal karena terlalu banyaknya paket menuju komputer server. Kinerja komputer dapat dilihat pada Tabel 1. 
Tabel 1 Performance CPU

\begin{tabular}{cc}
\hline Performance & Total \\
\hline CPU & $40 \% 3.09 \mathrm{Ghz}$ \\
Memory & $3.6 / 7.9 \mathrm{~GB}(46 \%)$ \\
Utilization & $40 \%$ \\
Speed & $3.09 \mathrm{GHz}$ \\
Processes & 195 \\
Thread & 1949 \\
Handles & 70948 \\
\hline
\end{tabular}

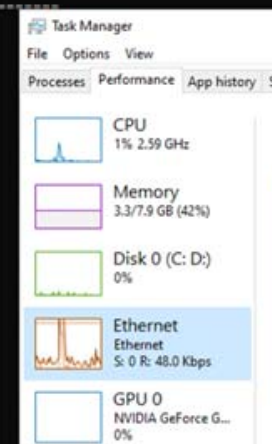

Aphistory Startup Users Details Services
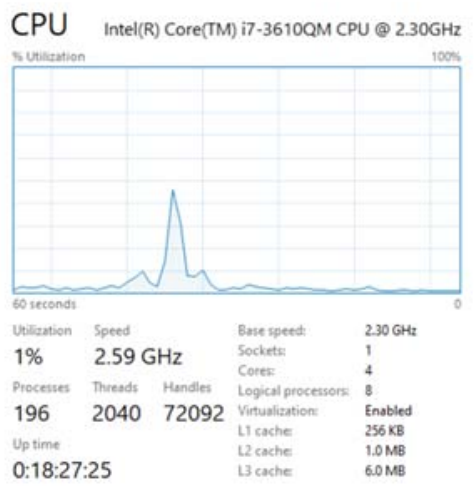

Q Fener details (1) Open Resource Monitor

Gambar 12 Grafik performance CPU

Pada Gambar 12, penyerangan dari komputer attacker telah diberhentikan sehingga grafik performa dari komputer server lebih rendah dan komputer server dapat melakukan pemrosesan secara stabil. Kinerja komputer server dapat dilihat pada tabel berikut.

Tabel 2 Performance CPU

\begin{tabular}{cc}
\hline Performance & Total \\
\hline CPU & $1 \% 2.59 \mathrm{Ghz}$ \\
Memory & $3.3 / 7.9 \mathrm{~GB}(46 \%)$ \\
Utilization & $1 \%$ \\
\hline
\end{tabular}




\begin{tabular}{cc}
\hline Performance & Total \\
\hline Speed & $2.59 \mathrm{GHz}$ \\
Processes & 196 \\
Thread & 2040 \\
Handles & 72092 \\
\hline
\end{tabular}

\section{Simpulan}

Berdasarkan penelitian yang dilakukan dapat disimpulkan bahwa sistem keamanan jaringan komputer menggunakan aplikasi SNORT dapat membantu administrator PT. Promanufacture Indonesia untuk meminimalisir terjadinya serangan dari pihak-pihak yang tidak bertanggung jawab.

\section{Daftar Pustaka}

[1] D. Wijanarko, "SISTEM KEAMANAN JARINGAN KOMPUTER MENGGUNAKAN SNORT," J. Teknol. Inf. dan Terap., vol. 2, no. 1, pp. 171-175, 2015.

[2] B. Sudradjat, "SISTEM PENDETEKSIAN DAN PENCEGAHAN PENYUSUP PADA JARINGAN KOMPUTER DENGAN MENGUNAKAN SNORT DAN FIREWALL | Journal of Information System, Applied, Management, Accounting and Research," JISAMAR J. Inf. Syst. Applied, Manag. Account. Res., vol. 1, no. 1, pp. 10-24, Dec. 2017, [Online].

Available: http://journal.stmikjayakarta.ac.id/index.php/jisamar/article/view/9.

[3] A. L. Ginting, J. Napitupulu, and J. Jamaluddin, "Sistem Monitoring Pendeteksian Penyusup Menggunakan Snort pada Jaringan Komputer Fakultas Ekonomi Universitas Methodist Indonesia," 2018, doi: 10.31227/osf.io/w5gt7.

[4] M. Ulfa, "IMPLEMENTASI INTRUSION DETECTION SYSTEM (IDS) DI JARINGAN UNIVERSITAS BINA DARMA,” J. MATRIK, vol. 15, no. 2, pp. 105-118, Aug. 2013, [Online]. Available: http://jurnal.binadarma.ac.id/index.php/jurnalmatrik/article/view/275.

[5] A. F. Mutaqin, "Rancang Bangun Sistem Monitoring Keamanan Jaringan Prodi Teknik Informatika Melalui SMS Alert dengan Snort," Nov. 2015. [Online]. Available: https://jurnal.untan.ac.id/index.php/justin/article/view/ 12537. 